\title{
МЕДЬСОДЕРЖАЩИЕ ПРОИЗВОДНЫЕ ИМИДАЗОЛОНОВ С РЕДОКС-АКТИВНЫМИ ГРУППИРОВКАМИ: СИНТЕЗ, ЦИТОТОКСИЧНОСТЬ И МЕХАНИЗМЫ ПРОТИВООПУХОЛЕВОГО ДЕЙСТВИЯ
}

\author{
Е.К. Белоглазкина, О.О. Красновская, А.В. Финько, Д.А. Гук \\ Химический факультет МГУ имени М.В. Ломоносова, \\ 119991, Россия, Москва, Ленинские горы, 1-3.
}

DOI: 10.19163/MedChemRussia2021-2021-120

E-mail: bel@org.chem.msu.ru

Представлены новые типы медьсодержащих координационных соединений на основе производных 2-халькоген-имидазол-4-онов, содержащих редокс-активные группировки (ферроценовые, селенидные, хиноновые) для повышения селективности их цитотоксического действия по отношению к опухолевым клеткам. Некоторые структурные типы исследованных лигандов представлены на схеме ниже.
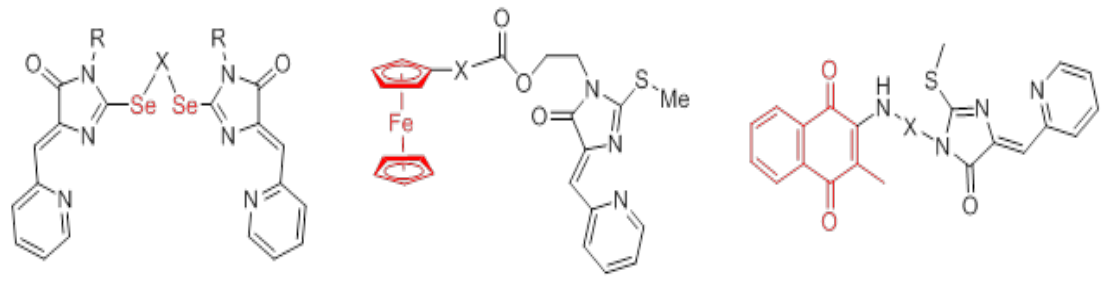

Указанные лиганды образуют в реакциях с солями меди моно- и биядерные координационные соединения, имеющие в составе $\mathrm{Cu}(\mathrm{I})$ и/или $\mathrm{Cu}(\mathrm{II})$. Большинство биологически активных координационных соединений меди, описанных в литературе, представляет собой комплексы Cu(II) из-за простоты синтеза и стабильности таких производных; в то же время, для проникновения медьсодержащих препаратов в клетку предпочтительна $\mathrm{Cu}(\mathrm{l})$. Для стабилизации иона меди в одновалентном состоянии мы предлагаем ввести в состав лиганда редокс-активный фрагмент, способный участвовать во внутримолекулярном восстановлении иона меди $\mathrm{Cu}(\mathrm{II}) \rightarrow \mathrm{Cu}(\mathrm{l})$.

На основании изучения цитотоксической активности полученных в работе координационных соединений выбран ряд соединений-лидеров, для которых исследован механизм цитотоксического действия и накопления в опухолевых клетках.

\section{Литература}

[1] D. Guk, O. Krasnovskaya, E. Beloglazkina, et al., SynOpen, 2020, 4, 38-43

[2] D. Guk, O. Krasnovskaya, E. Beloglazkina, et al., J.Med. Chem., 2020, 63, 13031-13063

[3] D. Guk, O. Krasnovskaya, E. Beloglazkina, et al., Dalton Trans., 2018, 47, 17357-17366 